\title{
Pengaruh Kecerdasan Emosional dan Kompetensi Komunikasi Terhadap Kinerja Karyawan PT. Bank Sulselbar Cabang Sidrap
}

\author{
A.Kartini Sari Putri $D^{* 1}$ \\ Andi Muhammad Hamdan²
}

\begin{abstract}
${ }^{1}$ Program Studi Manajemen, Sekolah Tinggi Ilmu Ekonomi Ichsan Sidenreng Rappang, Indonesia ${ }^{2}$ Program Studi Agribisnis, Politeknik Pertanian Negeri Pangkajene dan Kepulauan, Indonesia *e-mail: aksputrid@gmail.com ${ }^{1}$, $\underline{\text { ndyhamdan.77@gmail.com }}^{2}$
\end{abstract}

(Naskah masuk : 6 Mei 2021, Revisi : 18 Mei 2021, Publikasi : 25 Mei 2021)

\begin{abstract}
Abstrak
Penelitian ini dilatar belakangi oleh kinerja karyawan PT. Bank Sulselbar Cabang Sidrap yang memungkinkan bergantung dari beberapa faktor dari karyawan itu sendiri, seperti kecerdasan emosional dan kompetensi komunikasi yang selama ini diterapkan sehingga peneliti bertujuan untuk meneliti bagaimana pengaruh kecerdasan emosional dan kompetensi komunikasi terhadap kinerja karyawan pada PT. Bank Sulselbar Cabang Sidrap. Metode analisis yang digunakan dalam penelitian ini adalah metode deskriptif kuantitatif, analisis linear berganda, uji $t$, uji $F$, serta uji asumsi klasik dengan bantuan program Statistic Program for Social Science (SPPS). Hasil yang ditemukan dalam penelitian ini membuktikan bahwa kecerdasan emosional berpengaruh positif dan signifikan terhadap kinerja karyawan PT. Bank Sulselbar Cabang Sidrap, kompetensi komunikasi berpengaruh positif dan signifikan terhadap kinerja karyawan PT. Bank Sulselbar Cabang Sidrap, serta secara simultan kecerdasan emosional dan komunikasi berpengaruh signifikan terhadap kinerja karyawan pada PT. Bank Sulselbar Cabang Sidrap.
\end{abstract}

Kata kunci : Kecerdasan Emosional, Kompetensi Komunikasi, Kinerja Karyawan

\section{Abstract}

This research is motivated by the performance of the employees of PT. Bank Sulselbar, Sidrap Branch which is possible depends on several factors from the employees themselves, such as emotional intelligence and communication competence that have been applied so far, the researcher aims to examine how the influence of emotional intelligence and communication competence on employee performance at PT. Bank Sulselbar, Sidrap Branch. The analytical method used in this research is quantitative descriptive method, multiple linear analysis, $t$ test, $F$ test, and classical assumption test with the help of the Statistic Program for Social Science (SPPS) program. The results found in this study prove that emotional intelligence has a positive and significant effect on the performance of employees of PT. Bank Sulselbar, Sidrap Branch, communication competence has a positive and significant effect on the performance of employees of PT. Bank Sulselbar Sidrap Branch, and simultaneously emotional intelligence and communication have a significant effect on employee performance at PT. Bank Sulselbar, Sidrap Branch.

Keywords : Emotional Intelligence, Communication Competence, Employee Performance.

\section{PENDAHULUAN}

Pentingnya peranan sumber daya manusia bagi setiap organisasi, diharapkan dapat meningkatkan kinerja karyawan. Karena dalam kenyataan sehari-hari pun perusahaan sesungguhnya, hanya mengharapkan prestasi atau kinerja terbaik dari karyawannya (Sutrisno, 2010:155). Betapa tidak, persoalan kebutuhan memperoleh SDM unggul dan profesional, yang diharapkan oleh banyak badan usaha di Indonesia, baik badan usaha pemerintah maupun swasta untuk bisa bersaing dalam era globalisasi, sering kali hanya menjadi angan-angan semata.

Mitrani, Palziel, dan Fitt (Organisasi Industri Psikologi Amerika) telah banyak menemukan hasil studi, yang menunjukkan bahwa hasil tes sikap, pengetahuan dan prestasi akademik itu tidak dapat memprediksi kinerja atau keberhasilan hidup seseorang (Sutrisno, 2010:203). Temuan tersebut telah mendorong dilakukan penelitian lanjut pada perusahaan, mengenai variabel kompetensi yang diduga mempengaruhi kinerja karyawan. Byar dan Rue (Sutrisno, 2010:151) menyebutkan bahwa salah satu faktor yang dapat mempengaruhi kinerja 
karyawan adalah faktor individu/karyawan itu sendiri, yang tidak lain adalah kemampuan (ability).

Kemampuan (ability) seseorang didasarkan pada kecerdasan yang dimiliknya, karena kecerdasan merupakan determinan utama dari kinerja (Luthans, 2006:335). Salah satunya adalah kecerdasan emosional (Emotional Quotient), dimana disebutkan bahwa EQ yang tinggi akan menghasilkan kinerja yang baik pada semua pekerjaan (Luthans, 2006:335). Sehingga seorang karyawan yang memiliki EQ tinggi dapat dijadikan tolak ukur pencapaian kinerjanya. Kinerja karyawan juga dapat dipengaruhi oleh kemampuan berkomunikasi. Hal tersebut didukung oleh pernyataan yang dikemukakan Robbins dan Judge (2008:4), bahwa satu dari kekuatan terbesar yang merintangi kinerja karyawan yang berhasil adalah kurangnya komunikasi yang efektif.

Fenomena yang menjadi perhatian dalam penelitian ini adalah pada PT. Bank Sulselbar Cabang Sidrap yang beralamat di Jl. Jend. Sudirman No. 911, dengan SDM yang dimiliki sebanyak 36 karyawan. Masing-masing karyawan memiliki kemampuan, kepribadian, dan keterampilan yang berbeda-beda, sehingga dapat mencerminkan level kinerja karyawan. Namun faktanya, karyawan Bank Sulselbar cabang Sidrap yang memiliki kemampuan seperti EQ, belum tentu mampu mengindikasikan pencapaian kinerja. Diantaranya tingkat motivasi, pengendalian diri dan rasa empati, dimana hal tersebut dapat terlihat ketika karyawan Bank Sulselbar cabang Sidrapmenghadapi situasi yang menyulitkannya dalam bekerja, dan tidak memungkinkannya untuk membantu karyawan lain yang memiliki situasi serupa. Mereka memiliki cara masingmasing mengatasi hal tersebut. Disamping itu juga, kemampuan yang dimiliki oleh karyawan Bank Sulselbar Cabang Sidrap dalam berkomunikasi, belum tentu dapat mencerminkan level kinerja yang dimilikinya. Hal tersebut terlihat,ketika karyawan telahmenyampaikan saran atau ide-idebaru yang berhubungan dengan pekerjaan jarang dipertimbangkan, seolah itu kurang menarik. Walau demikian karyawan Bank Sulselbar Cabang Sidrap tetap menyelesaikan pekerjaan sesuai aturan dan prosedur yang telah ditetapkan perusahaan.

Berdasarkan fenomena tersebut, maka penulisingin menguji apakah terdapat pengaruh kecerdasan emosional dan kompetensi komunikasi terhadap kinerja karyawan, sehingga penulis tertarik melakukan penelitian dengan judul "Pengaruh Kecerdasan Emosional dan Kompetensi KomunikasiTerhadap Kinerja Karyawan PT. Bank Sulselbar Cabang Sidrap".

\section{TINJAUAN PUSTAKA}

\subsection{Kecerdasan Emosional (Emotional Quotient)}

Teori mengenai kecerdasan emosional, pertama kali dicetuskan oleh Salovey dan Mayer tahun 1990. Mereka (Solovey dan Mayer) mendefinisikan EQ (emotional quotient), sebagai kemampuan untuk memahami perasaan diri sendiri, untuk berempati terhadap perasaan orang lain dan untuk mengatur emosi, yang secara bersama berperan dalam peningkatan taraf hidup seseorang. Semula ide ini hanya diperkenalkan di sekitar lingkungan pendidikan saja. Dan mungkin tetap hanya akan beredar di sekeliling tembok sekolah, jika saja Daniel Goleman tidak memperkenalkan teori EQ ini dalam bukunya "Emotional Intelligence, Why It Can More Than IQ?” yang terbit di tahun 1995 (Mangkunegara, 2005:75).

a. Definisi Kecerdasan Emosional

Salovey dan Mayer mendefinisikan kecerdasan emosional atau yang sering disebut EQ, sebagai himpunan bagian dari kecerdasan sosial. Dimana dapat melibatkan kemampuan memantau perasaan sosial, yang melibatkan kemampuan pada orang lain, memilah-milah semuanya lalu menggunakan informasi ini untuk membimbing pikiran dan tindakan (Mangkunegara, 2005:76).

Menurut Robbins (2008:335), kecerdasan emosional (Emotional Intelligence) adalah kemampuan seseorang untuk mendeteksi serta mengelola petunjuk-petunjuk dan informasi emosional.Robbins (2008: 151) juga mengatakan berbagai studi mengemukakan bahwa kecerdasan emosional bisa memainkan peranan penting dalam pelaksanaan pekerjaan dan menjadi ciriorang yang berkinerja tinggi atau manusia yang berkualitas.Sedangkan, menurut Suharsono (2005:114), kecerdasan emosional adalah kemampuan untuk melihat, mengamati, 
mengenali bahkan mempertanyakan diri sendiri. Kecerdasan emosional tidak hanya berfungsi untuk mengendalikan diri, tetapi lebih dari itu juga mencerminkan kemampuan dalam mengelola ide, konsep, karya atau produk, sehingga hal itu menjadi minat orang banyak.

Menurut Davies dalam Casmini (2007:17) sendiri, kecerdasan emosi adalah kemampuan seseorang untuk mengendalikanemosi dirinya sendiri dan orang lain, membedakan satuemosi dengan lainnya, dan menggunakan emosi tersebut untuk menuntun proses berfikir serta perilaku seseorang.

b. Dimensi Kecerdasan Emosional

Goleman (2005:42) membagi dua bagiankecakapan emosi dalam kerangka kerja kecakapan emosi seperti berikut:

1). Kecakapan Pribadi, merupakan kecakapan yang menentukan bagaimana kita mengelola diri sendiri,terdiri dari:

a). Kecerdasan diri, mengetahui kondisi diri sendiri, kesukaan, sumber daya danintuisi.

b). Pengaturan diri, yaitu mengetahui kondisi, impuls, sumber daya diri sendiri.

c). Motivasi, yaitu kecenderungan yang mengantar atau memudahkan peralihan sasaran.

2). Kecakapan Sosial, merupakan kecakapan yang menentukan bagaimana kita menangani suatuhubungan. Kecakapan ini dapat dilihat dari:

a). Empati, yaitu kesadaran tehadap perasaan, kebutuhan dan kepentingan orang lain.

b). Keterampilan sosial, kepintaran dalam menggugah tanggapan yang dikehendakipada orang lain.

Dari pendapat Golemen dapat disimpulkan bahwa kecerdasan emosional akan memberikan kesadaran, yakni kesadaran diri atau awareness, yang merupakan kemampuan emosi paling penting untuk melatih self control. Kecerdasan emosional menjadikan seseorang mampu untuk mengenali diri, berempati, mencintai, berasosiasi dan dapat menyambut kesedihan dan kegembiraan secara lepas.

Adapun ciri-ciri seseorang dikatakan memiliki kecerdasan emosi yang tinggi apabila ia secara sosial mantap, mudah bergaul dan jenaka. Tidak mudah takutatau gelisah, mampu menyesuaikan diri dengan beban stres.Memiliki kemampuan besar untuk melibatkan diri dengan orang-orang atau permasalahan, untuk mengambil tanggung jawab dan memiliki pandangan moral. Kehidupan emosional mereka kaya, tetapi wajar, memiliki rasa nyaman terhadap diri sendiri, orang lain serta lingkungannya (Goleman, 2005:60-61).

Sedangkan, seseorang yangdikatakan memiliki kecerdasan emosi rendah apabila seseorang tersebut tidak memiliki keseimbangan emosi, bersifat egois, berorientasi pada kepentingan sendiridan tanpa memperdulikan sama sekali kepentingan orang lain, tidak dapat menyesuaian diri dengan beban atau masalah yang sedang dihadapi serta selalu merasa gelisah ketika menyelesaikan suatu pekerjaan.Keegoisan menyebabkan seseorang kurang mampu bergaul dengan orang-orang yang ada disekitarnya, karena mereka tersebut tidak memiliki penguasaan diri,sebaliknya cenderung dapat menjadi budak nafsu dan amarah yang diluapkan sendiri, serta mudah putus asa dan tengelam dalam kemurungan dan kebelengguan (Goleman, 2005:62).

\subsection{Kompetensi Komunikasi}

a. Definisi Kompetensi komunikasi

Spitzberg dan Cupach (Payne, 2005:21) mengemukakan kompetensi komunikasi adalah penilaian atas komunikasi yang berhasil, dimana tujuan dari mereka yang berinteraksi dipenuhi dengan menggunakan pesan-pesan yang dianggap tepat dan efektif didalam konteks organisasi tersebut. Hal tersebut ditekankan oleh Sutrisno (2010:159) bahwa yang dimaksud kemampuan berkomunikasi adalah dapat menyampaikan isi pikiran atau isi hati secara sistematis dan lancar kepada semua orang disegala lapisan secara meyakinkan, agar mereka percaya dan menyetujui hal-hal yang di ajukan. Sehingga kinerja yang ditunjukkan karyawan sesuai harapan karena hasil yang dicapai optimal.

b. Dimensi Kompetensi Komunikasi 
Menurut Charoenngam, Nongluck dan Jabin (Payne, 2005:25), bahwa indikator-indikator yang digunakan untuk mengukurtingkat kompetensi komunikasi dalam organisasi adalah sebagai berikut :

1). Bijaksana dan kesopanan, merupakan bentuk sikap seseorang dalam mengambil tindakan atau keputusan yang objektif, denganmemperhatikan etika, sopan santun, adil, dan tata krama.

2). Penerimaan umpan balik, merupakan kesiapan diri dalam menerima umpan balik dari bawahan, atasan dan rekan kerja.

3). Berbagi informasi, merupakan kemauan seseorang memberi dan menerima informasi dari berbagai pihak seputar masalah tertentu.

4). Memberikan informasi tugas, merupakan suatu bentuk kemauan seseorang menjelaskan mengenai apa, dimana, dan bagaimana menyelesaikan suatu pekerjaan.

5). Mengurangi ketidakpastian tugas, merupakan suatu bentukpembukaan atau penguasaan diri seseorang terhadap masalah atau pekerjaan yang dilakoninya melalui hubungan komunikasi.

\subsection{Kinerja}

Kinerja merupakan prestasi kerja, yaitu perbandingan antara hasil kerja dengan standar yang ditetapkan (Dessler, 2009:41).

a. Kinerja Karyawan

Definisi kinerja sumber daya manusia dinyatakan oleh beberapa ahlidiantaranya:

1). Dessler (2009:40) berpendapat kinerja (prestasi kerja) karyawan adalah prestasi aktual karyawan dibandingkan dengan prestasi yang diharapkan dari karyawan. Prestasi kerja yang diharapkan adalah prestasi standar yang disusun sebagai acuan sehingga dapat melihat kinerja karyawan sesuai dengan posisinya dibandingkan dengan standar yang dibuat. Selain itu dapat juga dilihat kinerja dari karyawan tersebut terhadap karyawan lainnya.Dessler menyebutkan bahwa kinerja sebagai perbandingan antara hasil kerja yang secara nyata dengan standar kerja yang ditetapkan.

2). Mangkunegara (2010:67), yaitu hasil kerja baik yang kuantitas maupun kualitas yang dicapai oleh seseorang dalam melaksanakan tugas sesuai tanggung jawab yang diberikan. Mangkunegara menjelaskan bahwa kinerja individu adalah hasil kerja baik dari segi kualitas maupun kuantitas berdasarkan standar kerja yang telah ditentukan. Kinerja karyawan adalah yang mempengaruhi seberapa banyak mereka memberi kontribusi kepada organisasi. Lebih lanjut mereka mengatakan bahwa terdapat 6 (enam) elemen yang menjadi ukuran kinerja karyawan, yaitu :

1). Kualitas, yaitu hasil pekerjaan yang telah dilakukan seseorang mendekati sempurna;

2). Kuantitas, yaitu jumlah yang dihasilkan atau jumlah aktivitas yang dapat diselesaikan;

3). Ketepatan waktu, dapat menyelesaikan tepat pada waktunya dan dapat memaksimalkan waktu yang tersedia untuk kegiatan lain;

4). Efektifitas, Pemanfaatan secara maksimal sumber daya yang ada pada organisasi untuk meningkatkan keuntungan dan mengurangi kerugian;

5). Kemandirian, dapat melakasanakan kerja tanpa bantuan guna menghindarihasil yang merugikan;

6). Komitmen kerja, komitmen kerja antara pegawai dengan organisasinya.

Penelitian Terdahulu

a. Repareni (2013)

Penelitian dengan judul "Analisis Pengaruh Kompetensi Komunikasi, Kecerdasan Emosional, dan Budaya Organisasi Terhadap Kinerja Karyawan Radio Republik Indonesia Palembang". Dalam penelitian ini yang digunakan adalah alat analisis regresi linear berganda denganmetode sensus. Adapun hasilnya adalahbahwa variabel kompetensi komunikasi (X1), kecerdasan Emosional(X2) dan budaya Organisasi(X3) baik itu secara parsial dan simultan mempunyai pengaruh yang positifdansignifikan terhadap kinerja Karyawan (Y).Sedangkan Nilai sifnifikansi variabel X1 sebesar 0,96, variabel X2 sebesar 0,61 dan variabel X3 0,165. Tingkat nilai signifikansi yang digunakan adalah $5 \%$. 
b. Edwardin (2006)

Penelitian dengan judul "Analisis Pengaruh Kompetensi Komunikasi, Kecerdasan Emosional, dan Budaya Organisasi Terhadap Kinerja Karyawan PT. POS Indonesia (Persero) se - kota Semarang". Penelitian ini menggunakan Structural Equation Modeling (SEM)dari paket software statistic AMOS dengan teknik analisis Regression Weight yang digunakan untuk meneliti seberapa besarvariabel-variabel penelitian yang saling mempengaruhi (variabel bebas dan dan variabel terikat). Adapun hasil penelitiannya yang secara parsial menunjukkan bahwa ada pengaruh yang positifdan signifikan antara variabel X1 yaitu kompetensi komunikasi $(0,026)$, variabel X2 yaitu kecerdasan emosional, $(0,048)$ dan variabel X3 yaitu budaya organisasi $(0,045)$ terhadap variabel Y yaitu kinerja karyawan. Sedangkan secara simultan diperoleh hasil yang signifikan. Tingkat signifikansi yang digunakan adalah sebesar $5 \%$.

c. Sani (2010)

Penelitian dengan judul "Analisis Pengaruh Burnout Dan Kecerdasan Emosional (EI) Terhadap Kinerja Pegawai PT. Bank Sulselbar Cabang Utama”.Penelitian ini menggunakan analisis regresi sederhana variabelbebas terhadap variabel terikat. Berdasarkan hasil penelitiannya di lapangan menunjukkan bahwa variabelBurnout dan Emotional Intelligence secara simultan mempunyai pengaruh yang positifdansignifikan terhadap kinerja karyawan $(P=0,046<0,05)$. Sedangkan secara parsial variabel burnoutmempunyai pengaruh positifdan signifikanterhadap kinerja $(\mathrm{P}=$ $0,035<0,05$ ) dan variabel EI mempunyai pengaruh positifdan signifikan terhadap kinerja karyawan $(\mathrm{P}=0,045<0,05)$ dengan tingkat signifikansi $5 \%$.

\section{KERANGKA PIKIR}

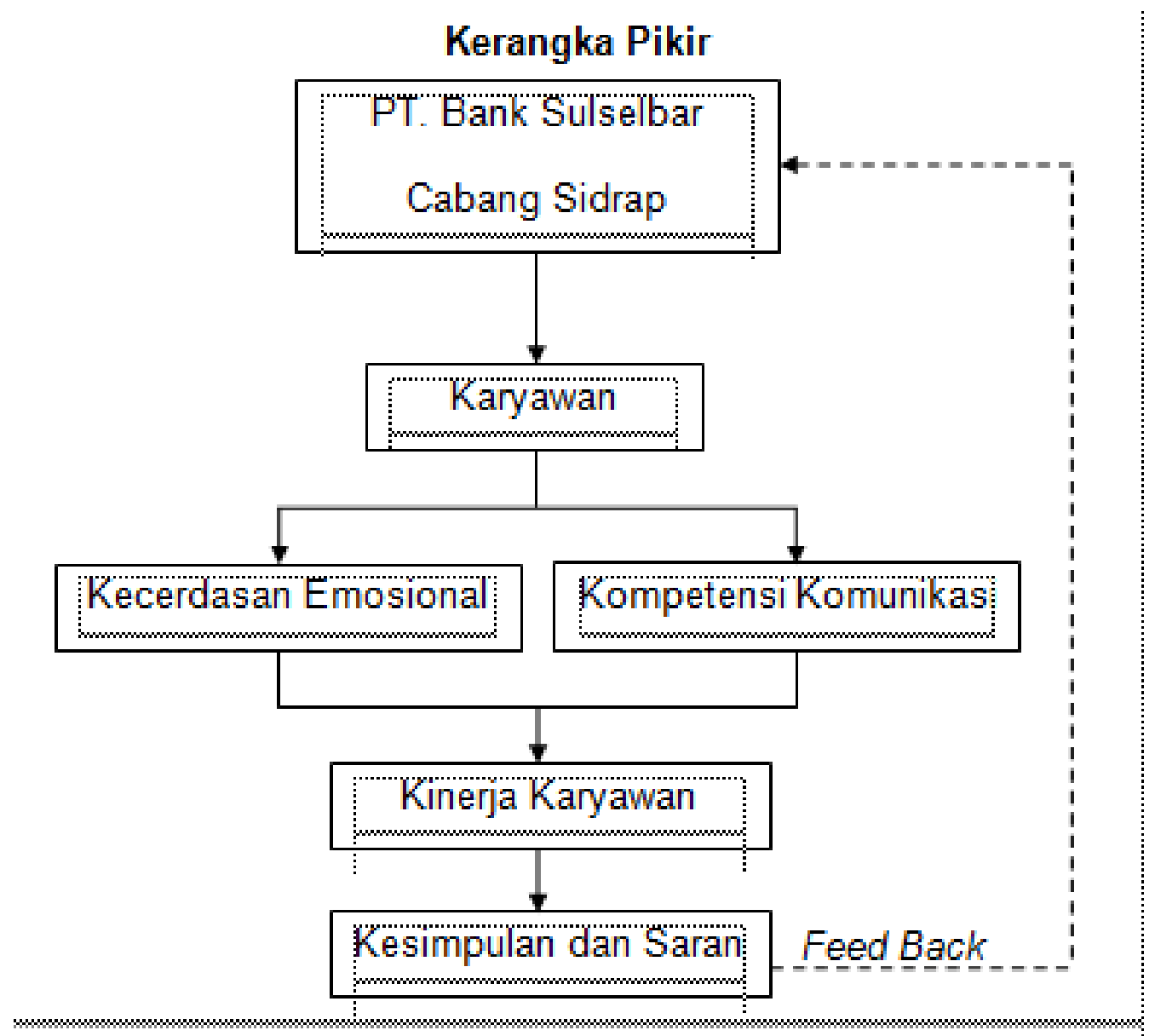

Gambar 1. Kerangka pikir 
PT. Bank Sulselbar Cabang Sidrapsaat ini memiliki jumlah karyawan sebanyak 36 orang dari beberapa unit bagian. Karyawan dengan ability yang berbeda-beda, berusaha menyelesaikan pekerjaan yang diemban kepadanya. Seperti kemampuan mengelola emosi baik itu diri sendiri maupun orang lain yang disebut EQ (Emotional Quotient) dan mampu menjalin hubungan kerja melalui kompetensi komunikasi yang efektif. Sehingga pada akhirnya berpengaruh pada tingkat kinerja masing-masing karyawan, dimana jika kinerja karyawan terus meningkat itu juga berdampak pada kinerja Bank Sulselbar CabangSidrap.

\section{HIPOTESIS}

ini sebagai berikut :

Berdasarkan pemaparan teori dan penelitian terdahulu, maka hipotesis pada penelitian

1. Kecerdasan emosional berpengaruh positif dan signifikan terhadap kinerja karyawan PT. Bank Sulselbar Cabang Sidrap.

2. Kompetensi komunikasi berpengaruh positif dan signifikan terhadap kinerja karyawan PT. Bank Sulselbar Cabang Sidrap.

3. Secara simultan variabel kecerdasan emosional dan kompetensi komunikasi berpengaruh signifikan terhadap kinerja karyawan PT. Bank Sulselbar Cabang Sidrap.

\section{METODE}

\subsection{Lokasi dan waktu Penelitian}

Penelitian ini dilakukan pada PT. Bank Sulselbar Cabang Sidrapyang beralamat di Jl. Jend. Sudirman No. 911 91611, dengan kurun waktu penelitian kurang lebih satu bulan.

\subsection{Jenis dan Sumber Data}

a. Jenis Data : Kualitatif (Deskripsi Bank Sulselbar) dan Kuantitatif (Absensi karyawan)

b. Sumber Data : Primer (Penyebaran Kuesioner) dan Sekunder (Dokumen dan laporan)

\subsection{Teknik pengumpulan Data}

a. Penelitian kepustakaan (library research).

b. Penelitian lapangan (field research).

Pada penelitian ini menggunakan skala Likert 1 sampai 5.

5: Sangat Setuju (SS) 4: Setuju (S) 3: Kurang Setuju (KS) 2: Tidak Setuju (TS)

1: Sangat Tidak Setuju (STS)

\subsection{Populasi dan Sampel}

a. Populasi : seluruh jajaran karyawan PT. Bank Sulselbar Cabang Sidrap yakni berjumlah 36 orang karyawan yang berasal dari beberapa unit bagian.

b. Sampel : Jumlah sampel yang diambil adalah 36 orang karyawan (sampel penuh (Martono, 2014:81).

\subsection{Analisis Data}

Metode analisis data dalam penelitian ini adalah metode kuantitatif yang menguji hipotesis berdasarkan data yang dikumpulkan dan teori/pendapat yang digunakan.

Analisis regresi linear berganda $\mathrm{Y}=\mathrm{a}+\mathrm{b} 1 \mathrm{X} 1+\mathrm{b} 2 \mathrm{X} 2+\mathrm{e}$

Dimana,

$\mathrm{Y}=$ Kinerja Karyawan $\mathrm{a}=$ Konstanta $\mathrm{b} 1=$ Koefisien regresi $\mathrm{X} 1$ b2=Koefisien regresi X2

$\mathrm{X} 1=$ Kecerdasan Emosional $\mathrm{X} 2=$ Kompetensi Komunikasi $\quad \mathrm{e}=$ Standar Error

Pengolahan dilakukan menggunakan paket software IBM SPSS Ver. 21.

\subsection{Uji Hipotesis :}

a. Uji t

Yaitu untuk menguji secara parsial (individu) masing-masing variabel bebas (X) terhadap varibel terikat (Y). kriteria pengujiannya yaitu : 
Dalam artian, jika thitung < ttabel maka H0 diterima dan H1 ditolak. Dan Sebaliknya. Sedangkan jika nilai signifikansi lebih besar dari nilai probability $(\alpha>0,05)$, maka H0 diterima dan Ha ditolak. Dan sebaliknya. Menurut Siregar (2014: 440) nilai ttabel dapat dicari dengan menggunakan suatu tabel t-student, berdasarkan pengujian dua sisi, maka nilai $\alpha$ dibagi dua. Dan rumus yang digunakan adalah ttabel $=\mathrm{t}(\alpha / 2),(\mathrm{n}-(\mathrm{k}-1)$. Dimana: $\alpha=$ nilai probability; $\mathrm{n}=$ jumlah sampel; $\mathrm{k}$ = variabel bebas.Uji t (parsial) akan dilakukan pada H1 dan H2.

b. Uji F

Yaitu untuk mengetahui pengaruh variabel bebas secara simultan(bersama-sama) terhadap variabel terikat. Ini dilakukan pada H3 dengan tingkat signifikansi 5\%.

Dalam artian, jika Fhitung < Ftabel maka H0 diterima dan Ha ditolak. Dan sebaliknya. Sedangkan jika nilaisignifikansi lebih besar dari nilai probability $(\alpha>0,05)$, maka HO diterima dan Ha ditolak. Dan sebaliknya. Menurut Siregar (2014: 409) nilia Ftabel dapat dicari dengan menggunakan tabel $F$, yaitu dengan rumus: $F$ tabel $=F(\alpha, d k a, d k b)$. Dimana $\alpha=$ nilai probability; dka penyebut $=$ jumlah variabel bebas; dkb pembilang $=\mathrm{n}-\mathrm{dka}-1(\mathrm{n}=$ jumlah sampel). Uji $\mathrm{F}$ (simultan) ini akan dilakukan pada pengujian hipotesis ketiga (H3).

\section{7. $\quad$ Koefisien Korelasi dan Koefisien Determinasi}

Menurut Sugiyono (2010: 278) nilai koefisien korelasi (R) menunjukkan bahwa seberapa besar korelasi atau hubungan antara variabel-variabel independen dengan variabel dependen. Koefisien korelasi dikatakan kuat apabila diatas 0,5 dan mendekati nilai 1. Sedangkan nilai koefisien determinasi ditentukan oleh kuadrat dari nilai koefisien korelasi. Koefisien determinasi digunakan untuk melihat besar kontribusi yang disumbangkan variabel indenpenden terhadap variabel dependen dengan cara mengalikannya dengan $100 \%(\mathrm{Kd}=\mathrm{r} 2 \mathrm{x}$ $100 \%)$

\subsection{Uji Instrumen}

a. Uji Validitas

Yaitu tingkat keandalan dan kesahihan alat ukur yang digunakan. Ketentuannya yaitu apabila nilai korelasi(correlation bivariate pearson) $>0,30$ maka instrumen yang digunakan dikatakan valid atau dalam keadaan signifikan (Sugiyono, 2012 :174).

b. Uji Reliabilitas

Untuk melihat sejauh mana instrumen alat ukur pada kuesioner tetap konsisten setelah dilakukan berulang-ulang terhadap subjek. Suatu instrumen dinyatakan reliabel, bila koefisien reliabilitas minimal 0,60. Realibilitas alat ukur (instrumen) akan diperlihatkan oleh nilai cronbach's alpha (Sugiyono, 2012: 174).

\subsection{Uji Alat Analisis Data}

a. Uji Normalitas

Yaitu bertujuan untuk menguji data variabel bebas (X) dan variabel terikat $(\mathrm{Y})$ pada persamaan regresi yang dihasilkan, apakah telah berdistribusi normal atau tidak normal. Model regresi yang baik adalah memiliki data yang berdistribusi normal atau mendekati grafik yaitu grafik Normality Probability Plot. Pengujian normalitas data menggunakan uji Kolmogorovsmimov one sampel test. Adapun kriteria uji jika probalibilitas signifikan > 0,05 maka data berdistribusi normal. Dasar pengambilan keputusan adalah :

1). Jika data menyebar disekitar garis diagonal dan mengikuti arah garis diagonal, maka model regresi memenuhi asumsi normalitas

2). Jika data menyebar jauh dari garis diagonal dan tidak mengikuti arah garis diagonal maka model regresi tidak memenuhi asumsi normalitas.

b. Uji Multikolinearitas

Yaitu adanya hubungan linear yang sempurna antara beberapa atau semua variabel bebas. Uji multikolinieritas bertujuan untuk menguji apakah model regresi yang ditemukan adanya korelasi antar variabel bebas. Model regresi yang baik adalah tidak terjadi korelasi di antara variabel bebas.Untuk mendeteksi ada tidaknyamasalah multikolinearitas yaitu dengan 
melihat tolerance value dan nilai VIF.Metode pengambilan keputusan untuk uji multikolinearitas yaitu jika tolerance $>0,1$ dan nilai VIF $<10$, maka model dapat dikatakan bebas dari masalah multikolinearitas.

c. Uji Heteroskedastisitas

Uji heteroskedastisitas bertujuan untuk menguji apakah dalam model regresi terjadi ketidaksamaan varians dari residual satu pengamatan ke pengamatan yang lain. Jika varians dari residual satu pengamatan ke pengamatan lain tetap, maka disebut homoskedastisitas dan jika berbeda disebut heteroskedastisitas.

Model regresi yang baik seharusnya tidak terjadi heteroskedastisitas, ini dapat dilihat dari grafik scatterplot. Dasar pengambilan keputusan pada uji heteroskedastisitas yakni:

1). Jka ada pola tertentu, seperti titik-titik yang membentuk pola tertentu yang teratur (bergelombang, melebar kemudian menyempit), maka mengindikasikan terjadi heterokedastisitas

2). Jika ada pola yang jelas serta titik-titik yang menyebar diatas dan dibawah angka 0 pada sumbu Y, maka tidak terjadi heterokedastisitas.

\section{HASIL DAN PEMBAHASAN}

Jumlah responden dalam penelitian ini adalah 36 orang yaitu karyawan PT. Bank Sulselbar Cabang Sidrap. Karakteristik yang dibahas meliputi jenis kelamin, usia, pendidikan terakhir dan masa kerja karyawan. Dari hasil survei diperoleh data-data karakteristik karyawan sebagai berikut

Tabel 1. Jenis Kelamin

\begin{tabular}{ccc}
\hline J K & Frek (org) & Persent (\%) \\
\hline Pria (1) & 27 & 75.00 \\
Wanita (2) & 9 & 25.00 \\
\hline Total & 36 & 100.00 \\
\hline
\end{tabular}

Tabel 2. Karakteristik Usia/Umur

\begin{tabular}{ccc}
\hline Umur & Frek (orang) & Persent (\%) \\
\hline $20-25$ th $(1)$ & 6 & 16.67 \\
$>25-30(2)$ & 7 & 19.44 \\
$>31-35(3)$ & 12 & 33.33 \\
$>36-40(4)$ & 6 & 16.67 \\
$>41(5)$ & 5 & 13.89 \\
\hline Total & 36 & 100.00 \\
\hline
\end{tabular}

Tabel 3. Tingkat Pendidikan

\begin{tabular}{ccc}
\hline Pend & Frek (orang) & Persent (\%) \\
\hline SMP (1) & 1 & 2.78 \\
SMA (2) & 10 & 27.78 \\
DIII (3) & 1 & 2.78 \\
S1 (4) & 23 & 63.89 \\
S2 (5) & 1 & 2.7 \\
\hline Total & 36 & 100.00 \\
\hline
\end{tabular}

Tabel 4. Masa Kerja

\begin{tabular}{ccc}
\hline Masa Kerja & Frek (orang) & Persent (\%) \\
\hline$<3$ tahun $(1)$ & 10 & 27.78 \\
$>3-6(2)$ & 6 & 16.67 \\
$>6-9(3)$ & 10 & 27.78 \\
$>9-12(4)$ & 5 & 13.89 \\
$>12(5)$ & 5 & 13.89 \\
\hline Total & 36 & 100.00 \\
\hline
\end{tabular}




\subsection{Uji Instrumen}

Berikut ini merupakan hasil uji instrumen menggunakan software IBM SPSS Ver. 21.

\begin{tabular}{|c|c|c|c|c|}
\hline \multicolumn{5}{|c|}{ Hasil Uji Validitas Instrumen } \\
\hline Variabel & Instrumen & $\mathbf{R}_{\text {hitung }}$ & $\mathbf{R}_{\text {kritis }}$ & Ket. \\
\hline \multirow{5}{*}{$\begin{array}{c}\text { Kecerdasan } \\
\text { Emosional (X1) }\end{array}$} & $\mathrm{X} 11$ & 0.743 & \multirow{5}{*}{0.30} & \multirow{5}{*}{ Valid } \\
\hline & $\mathrm{X} 12$ & 0.762 & & \\
\hline & $\mathrm{X} 13$ & 0.552 & & \\
\hline & $\mathrm{X} 14$ & 0.556 & & \\
\hline & $\mathrm{X} 15$ & 0.774 & & \\
\hline \multirow{5}{*}{$\begin{array}{c}\text { Kompetensi } \\
\text { Komunikasi (X2) }\end{array}$} & $\mathrm{X} 21$ & 0.717 & \multirow{5}{*}{0.30} & \multirow{5}{*}{ Valic } \\
\hline & $\mathrm{X} 22$ & 0.634 & & \\
\hline & $\mathrm{X} 23$ & 0.551 & & \\
\hline & $\mathrm{X} 24$ & 0.581 & & \\
\hline & $\times 25$ & 0.821 & & \\
\hline \multirow{6}{*}{$\begin{array}{c}\text { Kineria Karyawan } \\
(Y)\end{array}$} & $\mathrm{Y} 1$ & 0.817 & \multirow{6}{*}{0.30} & \multirow{6}{*}{ Valid } \\
\hline & Y2 & 0.593 & & \\
\hline & Y3 & 0.841 & & \\
\hline & Y4 & 0.520 & & \\
\hline & Y5 & 0.841 & & \\
\hline & Y6 & 0.517 & & \\
\hline
\end{tabular}

Gambar 2. Uji Validitas dari SPSS

\begin{tabular}{|c|c|c|c|}
\hline \multicolumn{4}{|c|}{ Hasil Uji Reliabilitas Instrumen } \\
\hline Variabel & $\begin{array}{c}\text { Cronbach's } \\
\text { Alpha }\end{array}$ & $\begin{array}{c}\text { Standar } \\
\text { Reliabilitas }\end{array}$ & Ket. \\
\hline $\begin{array}{c}\text { Kecerdasan } \\
\text { Emosional (X1) }\end{array}$ & 0.707 & 0.60 & Reliabel \\
\hline $\begin{array}{c}\text { Kompetensi } \\
\text { Komunikasi (X2) }\end{array}$ & 0.664 & 0.60 & Reliabel \\
\hline $\begin{array}{c}\text { Kineria Karyawan } \\
(Y)\end{array}$ & 0.826 & 0.60 & Reliabel \\
\hline
\end{tabular}

Gambar 3. Uji Reliabilitas dari SPSS

Sumber: Hasil Pengolahan data SPSS Ver 21

\subsection{Uji Asumsi Klasik}

Berikut ini merupakan hasil uji asumsi klasik menggunakan software IBM SPSS Ver. 21.

\begin{tabular}{|c|c|c|c}
\multicolumn{5}{c|}{ Uji Kolmogorov-smirnov } \\
\hline Variabel & Kolmogorov-Smirnov Z & Standar & Ket. \\
\hline $\begin{array}{c}\text { Kecerdasan } \\
\text { Emosional (X1) }\end{array}$ & 1.128 & 0.05 & normal \\
\hline $\begin{array}{c}\text { Kompetensi } \\
\text { Komunikasi (X2) }\end{array}$ & 0.982 & 0.05 & normal \\
\hline $\begin{array}{c}\text { Kinerja } \\
\text { Karyawan (Y) }\end{array}$ & 1.174 & 0.05 & normal
\end{tabular}

Gambar 4. Uji Normalitas dari SPSS

Uji Multikolinearitas
\begin{tabular}{|c|c|c|}
\hline Variabel bebas & Tolerance & VIF \\
\hline Kecerdasan Emosional (X1) & 0.854 & 1.172 \\
\hline Kompetensi Komunikasi (X2) & 0.854 & 1.172 \\
\hline
\end{tabular}

Gambar 5. Uji Multikolineritas dari SPSS

Sumber: Hasil Pengolahan data SPSS Ver 21

\subsection{Uji Heterokedastisitas}

Berikut ini merupakan hasil uji Heterokedastisitas menggunakan software IBM SPSS Ver. 21. 


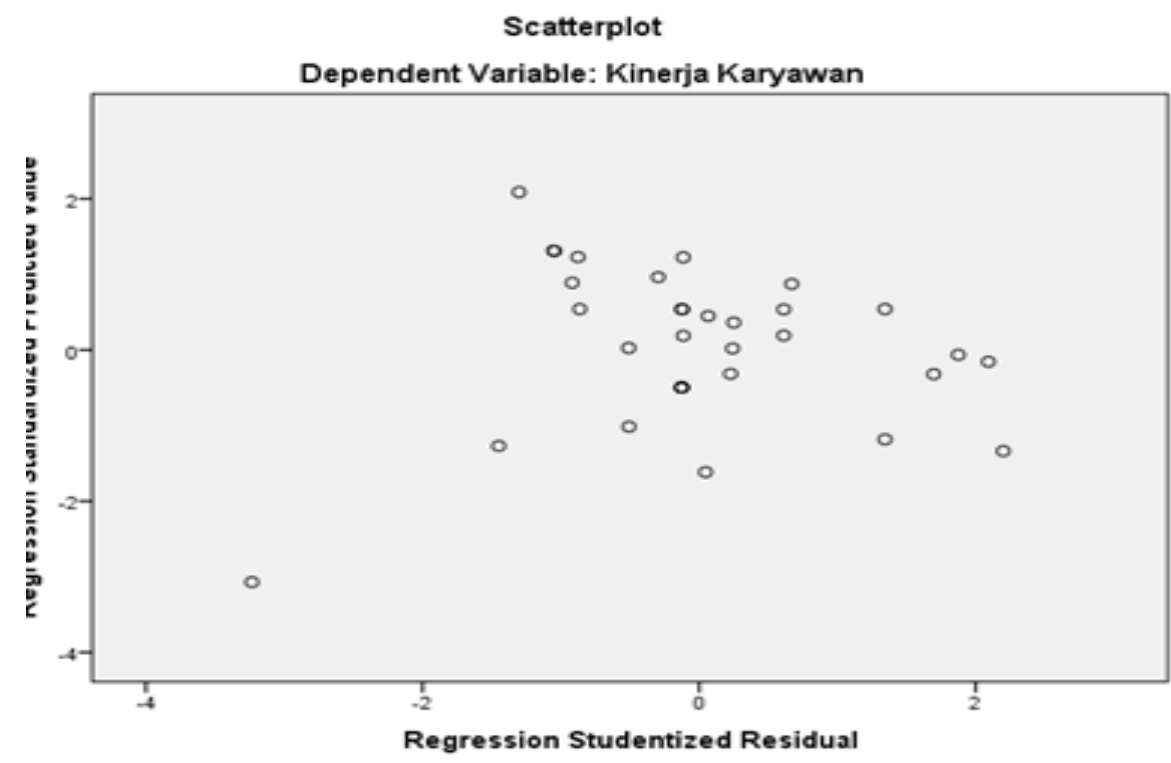

Gambar 6. Uji Heterodastisitas dari SPSS

Sumber: Hasil Pengolahan data SPSS Ver 21

\subsection{Analisis Data}

a. Analisis Regresi Berganda

\begin{tabular}{|l|c|c|c|c|c|}
\hline \multirow{3}{*}{ Model } & \multicolumn{2}{|c|}{ Knstandardiefizen Regresi } \\
\cline { 2 - 5 } & \begin{tabular}{c} 
d Coefficients \\
\cline { 2 - 5 }
\end{tabular} & $\begin{array}{c}\text { Standardized } \\
\text { Coefficients }\end{array}$ & \multirow{2}{*}{ T } & \multirow{2}{*}{ Sig. } \\
\cline { 2 - 5 } & $\begin{array}{c}\text { Std. } \\
\text { Error }\end{array}$ & Beta & & \\
\hline $\begin{array}{l}\text { (Constant) } \\
\text { Kecerdasan } \\
\text { Emosional }\end{array}$ & -0.956 & 0.499 & & -1.918 & 0.064 \\
\hline $\begin{array}{l}\text { Kompetensi } \\
\text { Komunikasi }\end{array}$ & 0.421 & 0.118 & 0.285 & 3.562 & 0.001 \\
\hline
\end{tabular}

Gambar 7. Koefisien Regresi dari SPSS

Sumber: Hasil Pengolahan data SPSS Ver 21

$$
\mathrm{Y}=-0.956+0.421 \mathrm{X} 1+0.825 \mathrm{X} 2
$$

Persamaan tersebut menunjukkan bahwa semua variabel bebas berkorelasi positif terhadap variabel terikat (kinerja karyawan). Konstan yang bernilai negatif telah mengindikasikan bahwa jika variabel bebas (kecerdasan emosional dan kompetensi komunikasi) bernilai nol maka variabel terikat (kinerja karyawan) akan bernilai sebesar -0,956. Asumsinya seperti apabila kecerdasan emosional dan kompetensi komunikasi mengalami penurunan atau dalam posisi rendah pada titik tertentu,maka kinerja karyawan juga mengalami penurunan satu kali lebih rendah pada titik tertentu dengan besarnya perubahan 0,956. Sedangkan koefisien regresi variabel X1 sebesar 0,421, menyatakan bahwa perubahan kenaikan variabel bebas mengenai kecerdasan emosional, mampu memberikan pengaruh positif dalam peningkatan kinerja karyawan sebesar $42,1 \%$. Dan koefisien regresi pada variabel X2 sebesar 0,825, yang menyatakan bahwa perubahan kenaikan variabel bebas mengenai kompetensi komunikasi, mampu memberikan pengaruh positif sebesar $82,5 \%$ dalam peningkatan kinerja karyawan. 


\begin{tabular}{c|c|c|c|c}
\multicolumn{7}{c}{ Model Summary } \\
\hline Model & $R$ & $\begin{array}{c}R \\
\text { Square }\end{array}$ & $\begin{array}{c}\text { Adjusted } R \\
\text { Square }\end{array}$ & $\begin{array}{c}\text { Std. Error of } \\
\text { the Estimate }\end{array}$ \\
\hline 1 & .906 & .820 & .809 & .23226 \\
\hline
\end{tabular}

Berdasarkan perhitungan dengan menggunakan program SPSS tersebut, maka diperoleh nilai koefisien korelasi (R) sebesar 0,906 yang menunjukkan bahwa hubungan antara variabel independen dan dependen sangat kuat karena memiliki nilai R positif dan mendekati nilai 1.

Kemudian koefisien determinasi ( $R$ square) sebesar 0,820 yang menunjukkan bahwa persentase kontribusi pengaruh variabel independen terhadap variabel dependen sebesar $82 \%$, ini berarti bahwa setiap perubahan kinerja karyawan, dapat dijelaskan oleh kedua variabel $\mathrm{X}$ yakni sebesar $82 \%$ dan selebihnya $18 \%$ dijelaskan oleh faktor-faktor lain yang tidak dijelaskan dalam penelitian ini.

\subsection{Uji Hipotesis Secara Parsial}

Dari hasil penelitian, diperoleh nilai ttabel $=\mathrm{t}(0.05 / 2),(36-(2-1))=\mathrm{t} 0.025,35=2,030$. Dimanajika thitung< ttabel maka HO diterima dan Ha ditolak. Sebaliknya jika thitung $>$ ttabel maka HO ditolak dan Ha diterima. Begitupunjika nilai signifikansi< $<(0,05)$, maka H0 ditolak dan Ha diterima.

a. Pengaruh Kecerdasan Emosional (X1) Terhadap Kinerja Karyawan (Y)

Variabel X1 yaitu kecerdasan emosional mempunyai thitung (3.562) > ttabel (2.030), maka dapat dikatakan bahwa variabel X1 yakni kecerdasan emosional telah berpengaruh terhadap kinerja karyawan, dan disamping itu juga nilai probability $0.001<0.05$ menunjukkan bahwa variabel kecerdasan emosional berpengaruh secara signifikan terhadap kinerja karyawan yang ada pada PT. Bank sulselbar Cabang Sidrap.

b. Pengaruh Kompetensi Komunikasi (X2) Terhadap Kinerja Karyawan (Y)

Variabel X2 yaitu kompetensi komunikasi mempunyai thitung (9.487) > ttabel (2.030), maka dapat dikatakan bahwa pada variabel X2 yaitu kompetensi komunikasi telah berpengaruh terhadapvariabel $Y$ yaitu kinerja karyawan, dan disamping itu juga nilai probability $0.000<0.05$ menunjukkan bahwa variabel kompetensi komunikasi berpengaruh secara signifikan terhadap kinerja karyawan yang ada pada PT. Bank sulselbar Cabang Sidrap.

\subsection{Uji Hipotesis Secara Simultan}

Untuk mengetahui apakah ada pengaruh secara simultan (bersama-sama) variabel independen, yaitu kecerdasan emosional dan kompetensi komunikasi terhadap variabel dependen kinerja karyawan, maka dilakukan uji F (uji simultan). Selanjutnya nilai nilai Fhitung akan dibandingkan dengan nilai Ftabel, nilia Ftabel dapat dicari dengan menggunakan tabel $\mathrm{F}$, yaitu dengan rumus: Ftabel= F( $2, \mathrm{dka}, \mathrm{dkb})$. Dimana 0 nilai probability; dka penyebut $=$ jumlah variabel bebas; $\mathrm{dkb}$ pembilang $=\mathrm{n}-\mathrm{dka}-1(\mathrm{n}=$ jumlah sampel $)$. Sehingga diperoleh nilai Ftabel $=$ $F(0.05,2(36-2-1))=F(0.05,2,33)=3,285$.

Dimana jika Fhitung< Ftabel maka H0 diterima dan Ha ditolak. Sebaliknya jika Fhitung> Ftabel maka H0 ditolak dan Ha diterima. Begitupun jika nilai signifikansi<? (0.05), maka H0 ditolak dan Ha diterima.

Hasil uji hipotesis secara simultan mengenai Pengaruh Kecerdasan Emosional dan Kompetensi Komunikasi Terhadap Kinerja Karyawan, dapat dijelaskan sebagai berikut :

Variabel independen yang terdiri dari kecerdasan emosional dan kompetensi komunikasi mempunyai Fhitung(75.300) > Ftabel (3.285). Ini menunjukkan bahwa variabel independen tersebut berpengaruh terhadap variabel dependen (kinerja karyawan). Disamping itu juga nilai signifikansi $0.000<0.05$, yang berarti bahwa variabel independen (kecerdasan emosional dan kompetensi komunikasi) berpengaruh secara signifikan terhadap kinerja karyawan pada PT. Bank Sulselbar Cabang Sidrap. 


\section{KESIMPULAN}

Berdasarkan dari hasil analisis dan pembahasan yang telah dilakukan, maka dapat ditarik beberapa kesimpulan dalam penelitian ini yaitu kecerdasan emosional berpengaruh positif dan signifikan terhadap kinerja karyawan PT. Bank Sulselbar Cabang Sidrap. Kompetensi komunikasi berpengaruh positif dan signifikan terhadap kinerja karyawan PT. Bank Sulselbar Cabang Sidrap. Secara simultan kecerdasan emosional dan kompetensi komunikasi berpengaruh signifikan terhadap kinerja karyawan PT. Bank Sulselbar Cabang Sidrap.

Adapun saran yang dapat diberikan sehubungan dengan hasil penelitian ini adalah Disarankan agar perusahaan perlu memperhatikan kecerdasan emosional demi meningkatkan kinerja karyawannya, alternatif yang tepat adalah dengan praktek seleksi karyawan, dimana tolok ukur potensi kecerdasan emosional calon karyawan, bisa digunakan untuk proses seleksi promosi karyawan yang dinilai mampu untuk mengatasi interaksi-interaksi stress tinggi dan tekanan tinggi. Tolak ukur semacam ini juga dapat digunakan untuk menunjukkankebutuhan pelatihan tentang kecerdasan emosional guna meminimalisir kemungkinan terjadinya kebosanan, stress kerja, konflik di tempat kerja, atau bahkan kekerasan di tempat kerja.

Perusahaan perlu memperhatikan peningkatan kompetensi komunikasi karyawandenganmemberikan penjelasan tentang apa yang harus dilakukan, seberapa baik merekamengerjakannya dan apa yang dapat dilakukan untuk meningkatkan kinerja jikasedang berada di bawah standar. Karena kompetensi komunikasi adalah kontributor terbesar bagi kinerja karyawan,maka perusahaan perlu membentuk forum komunikasi antaraatasan dan bawahan di seluruh bagian, sehingga memungkinkan bagi karyawan untuklebih termotivasi menyesuaikan komunikasi mereka dan lebih terampil dalammengkomunikasikan ide-ide mereka. Dan pada akhirnya, dapat meningkatkankinerja karyawan PT. Bank Sulselbar Cabang Sidrap.

Ada baiknya perusahaanuntuk lebih memonitoring karyawan terkait kinerja pribadi melalui tolak ukur atau penilaian kinerja individu yang jelas setiaptahunnya, dimana kinerja tersebut meliputi kemampuan dan keterampilan yangdimiliki oleh setiap karyawan. Sehingga karyawanakan terpacu untuk lebih berprestasi dengan bekerja sungguh-sungguh dan memperhatikankuantitas dan kualitas hasil kerja.

Disarankan untuk peneliti selanjutnya dapat meneliti mengenai faktor-faktor lain yang mempengaruhi kinerja karyawan. Dengan harapan apabila faktor-faktor lain yang diteliti tersebut merupakan faktor yang berpengaruh positif dan signifikan terhadap kinerja karyawan, maka dapat dijadikan sebagai tambahan referensi dasar pertimbangan pengambilan keputusan, sehingga dapat meningkatkan kinerja karyawannya yang secara langsung maupun tidak langsung akan berpengaruh pula pada perkembangan dan kemajuan perusahaan yang bersangkutan.

\section{DAFTAR PUSTAKA}

Casmini. (2007). Emosional Parenting: Dasar-Dasar Pengasuhan Kecerdasan Emosi Anak,Yogyakarta: Pilar Mediaciti.

Dessler, G. (2009). Manajemen SDM. buku 1, Jakarta: Indeks.

Edwardin, S, A, T, Laras,(2006). "Analisis Pengaruh Kompetensi Komunikasi, Kecerdasan Emosional, dan Budaya Organisasi Terhadap Kinerja Karyawan PT. POS Indonesia (PERSERO) se-kota Semarang",Tesis. Universitas Diponegoro Semarang: Program Pascasarjana Pada Program Magister Manajemen.

Goleman, D. (2005). Kecerdasan Emosi: Untuk Mencapai Puncak Prestasi. Terjemahan Alex tri Kantjono, (2005), Jakarta: PT Gramedia Pustaka Utama. 
Karim, K. (2015). Manajemen Sumber Daya Manusia. Malang: Dream Litera.

Luthans, F. (2006), Perilaku Organisasi. Terjemahan Vivin AndikaY, Shekar P, Arie P, dan Winong R, Yogyakarta: ANDI.

Mangkunegara, A. P. (2005). Evaluasi Kinerja SDM, Bandung: Refika Cipta Rosdakarya.

,$-(2010)$. Manajemen Sumber Daya Manusia, Bandung:Remaja

Martono, N. (2014). Metode Penelitian Kuantitatif: Analisis Isi dan Analisis Data Sekunder, Edisi Rev.2, Jakarta: PT. RajaGrafindo Persada.

Mathis, R,L. dan Jackson, J,H, (2006). Human Resource Management:Manajemen Sumber Daya Manusia. Terjemahan Dian Angelia, Jakarta: Salemba Empat.

Payne, H.J. (2005). "Reconceptualizing Social Skills in Organizations : Exploring theRelationship Between Communication Competence. Job performance and supervisory roles". Journal of Leadership \& Organizational Studies, Vol 11, No. 2

Reparani, Y. (2013). "Analisis Pengaruh Kompetensi Komunikasi, Kecerdasan Emosional, dan Budaya Organisasi Terhadap Kinerja Karyawan Radio Republik Indonesia Palembang", Jurnal Ekonomi dan informasi Akuntansi, Vol.3 no.1 : 38-46.

Robbins, S. P dan Judge, T.A, (2008). Perilaku Organisasi: Organizational Behavior, (12th Edition), New Jersey: Pearson Education, Inc. Terjemahan Diana A. Jakarta: Salemba Empat.

Sani,A. (2010). "Analisis Pengaruh Burnout dan Kecerdasan Emosional (EI) Terhadap Kinerja Pegawai PT Bank Mega Syari'ah Cabang Malang”, Skripsi, Malang: Fakultas Ekonomi Jurusan Manajemen, Universitas Islam Negeri (UIN) Maliki Malang.

Simanjuntak, P. J. (2005). Manajemen dan Evaluasi Kerja, Jakarta: Lembaga Penerbit FEUI.

Siregar, S. (2014). Statistik Parametrik Untuk Penelitian Kuantitatif, edisi pertama. Jakarta: Bumi Aksara.

Sugiyono. (2010). Metode Penelitian Kuantitaif Kualitatif dan R\&D, Bandung: Alfabeta. . (2012). Metode Penelitian Kuantitaif Kualitatif dan R\&D, Bandung: Alfabeta.

Suharsono. 2005. Melejit IQ, EQ, IS. Depok: Inisiasi Press.

Sutrisno, E. (2010). Manajemen Sumber Daya Manusia, Jakarta:Prenada Media Group. www.banksulselbar.co.id, diakses pada tanggal 23 Februari 2020.

http://junaidichaniago.wordpress.com, diakses pada tanggal 26 Februari 2020. 
